\title{
SYNERGISTIC EFFECTS OF BINARY MIXTURES OF LINALOOL WITH PYRETHROIDS AGAINST FALL ARMYWORM
}

\author{
EFEITOS SINÉRGICOS DE MISTURAS BINÁRIAS DE LINALOL COM \\ PIRETROIDES CONTRA LAGARTA-DO-CARTUCHO
}

\section{Sérgio Macedo SILVA ${ }^{1}$; João Paulo Arantes Rodrigues da CUNHA ${ }^{2}$; César Henrique Souza ZANDONADI ${ }^{3}$; Heli Heros Teodoro de ASSUNÇÃ̃ ${ }^{4}$; Matheus Gregorio MARQUES ${ }^{5}$}

1. Professor, Universidade Federal dos Vales do Jequitinhonha e Mucuri, Instituto de Ciências Agrárias, Campus Unaí, Unaí, MG, Brasil.sergio.macedo@ufvjm.edu.br; 2. Professor, Universidade Federal de Uberlândia, Instituto de Ciências Agrárias, Campus Glória, Uberlândia, MG, Brasil; 3. Coordenador de Tecnologia de Aplicação, Forquímica, Goiânia, GO, Brasil; 4. Professor, Universidade Federal do Mato Grosso, Instituto de Ciências Agrárias e Tecnológicas, Campus Universitário de Rondonópolis, Rondonópolis, MT, Brasil; 5. Mestrando, Universidade Federal de Uberlândia, Instituto de Ciências Agrárias, Campus Glória, Uberlândia, MG, Brasil.

ABSTRACT: The present work aimed to determine the toxicity of linalool and evaluate the lethal and toxic effects of linalool associated with pyrethroids in binary mixtures to fall armyworm (Spodoptera frugiperda). The insects used in the experiment were obtained from stock breeding initiated from larvae collected from conventional corn plants, grown in an experimental area, in the city of Uberlândia, Minas Gerais. Also, it was obtained essential oil from a variety of Ocimum basilicum, with a high content of linalool $(80 \%)$, found naturally, as a measure of comparison of different linalool $(97.5 \%)$ assays. Dose-response bioassays with 3 rd instar larvae were performed to determine lethal dose for $50 \%$ mortality $\left(\mathrm{LD}_{50}\right)$ of linalool. Toxicity tests were also performed with $O$. basilicum essential oil and with pyrethroid insecticides: deltamethrin and its commercial product (Decis $25 \mathrm{EC}$, Bayer ${ }^{\mathbb{B}}$ ). After this, combinations between different doses of these products were made and applied on 3rd instar larvae of Spodoptera frugiperda (Smith). Linalool presented high toxicity to $S$. frugiperda $\left(\mathrm{LD}_{50}=0.177 \mu \mathrm{L}\right.$ a.i. $\left.\mu \mathrm{L}^{-1}\right)$. It was observed neurotoxic effects after the linalool application since the insects presented an aspect of confusion, followed by extreme agitation and finally death. All binary mixtures caused mortality higher than the products applied alone (deltamethrin and linalool) used at $100 \% \mathrm{LD}_{50}$, except to $75 \% \mathrm{LD}_{50}$ deltamethrin added to $25 \% \mathrm{LD}_{50}$ linalool, whose mortality did not differ the products alone, in 24 hours. It was obtained over $90 \%$ larval mortality when linalool was combined with $25 \% \mathrm{LD}_{50}$ of deltamethrin, in 24 and 48 hours after application, and over $80 \%$ of mortality when linalool was combined with $25 \% \mathrm{LD}_{50}$ of Decis, only in 48 hours after application. We conclude that linalool is a potential insecticidal and can be associated with pyrethroids to control of $S$. frugiperda. Further studies are required in order to evaluate the synergistic combinations against field populations of $S$. frugiperda.

KEYWORDS: Deltamethrin. Insecticidal activity. Spodoptera frugiperda. Synergism. Terpenoids.

\section{INTRODUCTION}

Spodoptera frugiperda (Smith, 1797) (Lepidoptera: Noctuidae) is the main insect pest of the corn crop in Brazil, causing losses up to $100 \%$ in production if control measures are not realized (MURÚA et al., 2015). Because it is a polyphagous insect and has high reproductive capacity in several crops, the main management tactics adopted lately to reduce population are chemical control by using synthetic insecticides or biological control for conventional hybrids as well as the use of genetically modified plants (MALONE; GATEHOUSE; BARRATT, 2008).

In this context, the indiscriminate and intensive use of synthetic insecticides caused a selection of insect pest populations resistant to different groups of insecticides, further compromising the use of chemical control (OMOTO et al., 2015; SANTOS-AMAYA et al., 2017). As an example, acetylcholinesterase (AChE), a key enzyme of the insect cholinergic system and target of organophosphorus and carbamates insecticides, has become insensitive to these molecules (WANG et al., 200). Consequently, this has increased product development by the chemical industry to provide new molecules that effectively integrate insect pest management and make agricultural production more sustainable (LANGAT et al., 2011).

Researchers have tested natural or plantderived products efficacy (BAGAVAN et al., 2009; SILVA et al., 2016), as well as associated molecules in the same formulation, searching safer alternatives 
for resistance management to insecticides (ISMAN; MIRESMAILLI; MACHIAL, 2011; RADHIKA; SAHAYARAJ, 2014).

Recent studies have focused on a combination of molecules with different mechanisms of action, wide spectrum of action, selectivity for non-target organisms, and the possibility of higher efficacy combined with synthetic products so that molecules do not lose quickly their effectiveness (LANGAT et al., 2011). It is known that associations between different products can promote greater toxicity to insects, since a compound can potentiate the action of another active ingredient by weakening the insect detoxification system, acting on the inhibition of P450 enzymes and esterase's (FAZOLIN et al., 2016).

In addition to the plant-insect interaction mechanism, linalool is a terpenoid that has proven to be effective in the control of sucking insects and defoliants in vitro (FARAONE, HILLIER, CUTLER, 2015), mainly affecting the transmission of nerve impulses by inhibiting the acetylcholinesterase enzyme (LOPEZ; VILLALOBOS, 2010). This compound, produced by secondary plant metabolism, can be found in high concentrations in the essential oils of some varieties of Aniba rosaeodora Ducke (Lauraceae) and Ocimum basilicum L. (Lamiaceae).

Effects observed during toxicological tests and attributed to these oils are due to the action of several essential oil compounds, which cannot be assigned exclusively to linalool. There are doubts about the toxicological effects of linalool exclusive application on $S$. frugiperda, as the possible synergistic effects over this pest mortality when linalool and synthetic insecticides were combined. Terpenoids and pyrethroids insecticides have different chemical structures and mechanisms of action, but they cause similar toxicity to pests, such as rapid nervous breakdown (KARIUKI et al., 2014). However, it is necessary more studies about the compatibility and efficacy of this combination to enable its use at crop protection against insect-pest. In addition, the synergistic effect may lead to the reduction of pesticide application which would be less harmful to the environment.

If this is the case, a safer, easier, and more sustainable tool to assist in the management of pest resistance to insecticides may be feasible. Therefore, the present work aimed to determine the toxicity of linalool and evaluate the lethal and toxic effects of linalool associated with pyrethroids in binary mixtures to fall armyworm (Spodoptera frugiperda).

\section{MATERIAL AND METHODS}

\section{Obtaining and rearing caterpillars}

In order to obtain the caterpillars, an area of $6,000 \mathrm{~m}^{2}$ was prepared at the Experimental Farm "Capim Branco", belonging to the Federal University of Uberlândia, (Uberlândia, Minas Gerais State, Brazil) for corn cultivation. The farm is situated at an altitude of 842 meters, with geographical coordinates $18^{\circ} 53^{\prime} \quad 23.46^{\prime \prime} \mathrm{S}$ of latitude and $48^{\circ} 20^{\prime} 27.46^{\prime \prime} \mathrm{W}$ of longitude, flat topography, and Aw climate type (Tropical humid with winter dry).

Conventional corn hybrid BM709 (Helix Sementes Ltda, Patos de Minas, Minas Gerais State, Brazil) was sown on March 14, during the second crop of 2018, in crop lines spaced $0.5 \mathrm{~m}$ and population density of 65.000 plants $\mathrm{ha}^{-1}$. Fertilization, located in the culture line, with NPK formulation 4-14-8 with a dose of $350 \mathrm{~kg} \mathrm{ha}^{-1}$, according to the culture requirement. When reaching the phenological stage of $\mathrm{V} 7$, the crop received cover fertilization of NPK formulation 20$05-20$, at a dose of $350 \mathrm{~kg} \mathrm{ha}^{-1}$.

Spodoptera frugiperda caterpillar gathering occurred after the beginning of the crop infestation, in the first phenological stages. For this, highly infested plants were randomly selected and had the cartridge (inner leaves not yet fully opened) removed, containing the insects. Then, the caterpillars were identified to compose a reared population at the laboratory, being maintained with a natural diet, containing leaves of the same cultivated hybrid.

Due to the defensive behavior (cannibalism) of $S$. frugiperda, each larva was individualized in disposable plastic pots of $300 \mathrm{~mL}$ containing $50 \mathrm{~cm}^{2}$ of fresh corn leaf, as a natural diet. After the individualization, the pots were conditioned in an air-conditioned room at $25 \pm 2^{\circ} \mathrm{C}, 60 \pm 10 \%$ relative humidity, and 12-hour photo phase. Until the complete development of the caterpillar and change to the pupa stage, the natural diet was replaced daily. During this stage, these were placed in Petri dishes lined with filter paper and kept inside screened cages.

After adult emergence, the moths were kept in cylindrical PVC cages $(150 \times 200 \mathrm{~mm})$, lined with filter paper and fed with honey and beer yeast (1: 1), as well as a cotton swab, moistened daily. The egg mass deposited on the filter paper was removed daily and wrapped in Petri dishes until the larvae hatch, and the same natural diet was immediately provided. In all stages of insect 
breeding, the climatic conditions were identical to those described previously.

\section{Ocimum basilicum L. essential oil obtaining}

The essential oil was extracted from leaves and flowers of $O$. basilicum ("Maria Bonita" variety), held in the experimental area of the Federal University of Uberlandia. The material originated from access PO 197442, from the Germplasm Bank North Central Regional PI Station, Iowa State University, USA, and provided by the Aromatic Plant Breeding Program of the Federal University of Sergipe. This variety presented mean values over $80 \%$ of linalool in the chemical composition (SILVA et al., 2017) (Table 1), which was used in the present study as a comparison measure in toxicological evaluations.

Then, to confirm the quantity of each compound, it was realized a new chemical analyzes of the essential oil, being performed on a gas chromatograph coupled with a mass spectrometer (Shimadzu GC-2010 + QP-5000), provided with a fused silica capillary column DB-5 (30 m x 0.25 mm x $025 \mu \mathrm{M}$ ), in according to methodology used by Silva et al. (2017). The operation mode was: helium as carrier gas at $1.7 \mathrm{ml} \mathrm{min}-1$, temperatures of $240{ }^{\circ} \mathrm{C}$ of injector, a detector of $230^{\circ} \mathrm{C}$, and the program of temperature of 60 to $240{ }^{\circ} \mathrm{C}, 3{ }^{\circ} \mathrm{C}$ increase every minute, $1 / 2$ being split and flow $1 \mathrm{ml}$ $\min ^{-1}$. The identification of compounds was performed by comparison of their mass spectra with the system databases and literature (MCLAFFERTY; STAUFFER, 1989) and determined whether the Kovats retention indices, comparing them with the literature (ADAMS, 2007).

The quantification of the compounds was performed on a gas chromatograph coupled with a flame ionization detector (Shimadzu GC-2010/ FID) and DB5 capillary column. The carrier gas was helium with a flow of $1.0 \mathrm{ml} \mathrm{min} \mathrm{m}^{-1}$ and split ratio of $1 / 20$, the injector to $240{ }^{\circ} \mathrm{C}$, detector to $230{ }^{\circ} \mathrm{C}$ and the program of temperature was $60{ }^{\circ} \mathrm{C}$ to $165^{\circ} \mathrm{C}$, with the addition of $4{ }^{\circ} \mathrm{C} \min ^{-1}$ from $165^{\circ} \mathrm{C}$ to 240 ${ }^{\circ} \mathrm{C}$ with an increase of $10^{\circ} \mathrm{C} \mathrm{min}^{-1}$.

\section{Toxicological evaluations}

Dose-response bioassays were performed with linalool (Quinarí - Casa das Essências, Ponta Grossa, Rio Grande do Sul State, Brazil, with 97.5\% purity), and the lethal dose $50\left(\mathrm{LD}_{50}\right)$ for $S$. frugiperda was determined. The tests were carried out in six-well cell culture plates maintained in an air-conditioned chamber $\left(25 \pm 1^{\circ} \mathrm{C}, 65 \pm 10 \% \mathrm{RH}\right.$, and 12-hour photo phase). In each well, the natural diet and a third instar larva of $S$. frugiperda were conditioned. The determination of the stages of development of larvae was performed according to Parra; Carvalho (1984). The acute toxicity tests were performed according to the methodology proposed by the "Organization for Economic Cooperation and Development" (OECD/OCDE, 2020), that establish methods for laboratory tests to assess the impact of pesticides on insects.

Solutions for determination of $\mathrm{LD}_{50}$ were prepared in acetone. A dilution range with the product was prepared with concentrations (v/v) ranging from $100 \%$ (pure) to $1 \%$, with each caterpillar being topically applied $1 \mu \mathrm{L}$, using a microsyringe (0.5-5 $\mu \mathrm{L}$ volume, Hamilton), which allows a precision volume of $0.5 \mu \mathrm{L}$. For each concentration evaluated, 24 third instar larvae were used.

Subsequently, the cell culture plates containing the insects were maintained in similar conditions as described above. The evaluations occurred every 24 hours after the application, counting the number of dead larvae. A negative control treatment was also performed, only with the acetone application. The insects that received the different concentrations of linalool were observed for 1 hour, to characterize the behavioral effects caused after the applications.

The toxicity tests with $O$. basilicum essential oil, as a natural source of linalool, and with pyrethroid insecticides were also performed: deltamethrin (purity 99.5\%, Pestanal®) and its commercial product (Decis $25 \mathrm{EC}$, Bayer $\AA$ ), in according to methodology used by Silva et al. (2017). For this, a dilution range of each of the products was prepared in acetone, covering the following concentrations: 0.1 to $1 \mu \mathrm{L}^{-1}$ for essential oil, 0.1 to $0.1 \times 10^{-4} \mu \mathrm{g} \mu \mathrm{L}^{-1}$ of deltamethrin and from 25 to $0.25 \mathrm{~g} \mathrm{~L}^{-1}$ of Decis. Again, each of the 24 caterpillars received, per each concentration the topical application of $1 \mu \mathrm{L}$ of a respective insecticide concentration or the essential oil and maintained as previously described. Dead larvae were counted every 24 hours after the application.

\section{Synergistic effect between linalool and pyrethroids}

After determining the lethal dose of linalool and pyrethroids, the following $\mathrm{LD}_{50}$ doses: $25 \%$ $\mathrm{LD}_{50}, 50 \% \mathrm{LD}_{50}$, and $75 \% \mathrm{LD}_{50}$ of each product were established.

Again, third instar caterpillars received the topical application of $1 \mu \mathrm{L}$ of the following treatments: $\mathrm{LD}_{50}$ deltamethrin $+\mathrm{LD}_{50}$ linalool; $\mathrm{LD}_{50}$ deltamethrin $+50 \% \quad \mathrm{LD}_{50}$ linalool; $50 \% \mathrm{LD}_{50}$ 
deltamethrin $+50 \% \mathrm{LD}_{50}$ of linalool; $50 \% \mathrm{LD}_{50}$ deltamethrin $+\mathrm{LD}_{50}$ linalool; $75 \% \quad \mathrm{LD}_{50}$ deltamethrin $+25 \% \mathrm{LD}_{50}$ linalool; $25 \% \mathrm{LD}_{50}$ deltamethrin $+75 \% \quad \mathrm{LD}_{50}$ linalool. For the commercial product, the following combinations were made: $\mathrm{LD}_{50}$ Decis $+\mathrm{LD}_{50}$ linalool; $75 \% \mathrm{LD}_{50}$ Decis $+25 \% \mathrm{LD}_{50}$ linalool; $50 \% \mathrm{LD}_{50}$ Decis $+50 \%$ $\mathrm{LD}_{50}$ linalool; $25 \% \mathrm{LD}_{50}$ Decis $+75 \% \mathrm{LD}_{50}$ linalool; $50 \% \mathrm{LD}_{50}$ Decis $+\mathrm{LD}_{50}$ linalool. All experimental conditions were identical to those described previously. The mortality data were obtained at 24 and 48 hours for each treatment.

\section{Data analysis}

The mortality data of each of the assays were submitted to the analysis of the dose-response type, using the tool "Probit" of SPSS Software (2011). Based on the mathematical model adjusted for the observed data, the $\mathrm{LD}_{50}$ values of the products were determined, as well as the value of the confidence interval, chi-square, and degrees of freedom. The difference between median lethal concentrations or dose of insecticide was considered statistically significant when $95 \%$ confidence intervals were non-overlapping. On the other hand, the data obtained from the mortality of insecticides combinations were submitted to the Shapiro Wilk test of normality distribution of residues, Levene homogeneity of variances, and Tukey's block additivity test, at 0.01 significance. When pertinent, the $\mathrm{F}$ test was performed by analysis of variance and the means compared by the Scott-Knott Test, at 0.05 significance.

\section{RESULTS}

\section{Acute toxicity}

In Table 1, the compounds of $O$. basilicum L. essential oil used as a comparison measure for linalool. The essential oil content found was $2 \%$ of $O$. basilicum biomass used. The gas chromatography-mass spectrometry analyses of $O$. basilicum essential oil revealed the presence of 19 compounds and the main components were linalool, 1,8-cineole and geraniol. The chemical composition was similar to results presented by Silva et al. (2017).

Table 1. Chemical composition of Ocimum basilicum L. essential oil obtained by gas chromatography and mass spectrometer.

\begin{tabular}{ccccccc}
\hline Peak & Retention time & CRI $^{\mathbf{1}}$ & LRI $^{\mathbf{2}}$ & Compound & \%Area & \%GC-FI $^{\mathbf{3}}$ \\
\hline 1 & 8.809 & 923 & 932 & $\alpha$-pinene & 0.01 & 0.14 \\
2 & 10.029 & 963 & 969 & sabinene & 0.11 & 0.17 \\
3 & 10.156 & 967 & 974 & $\beta$-pinene & 0.53 & 0.47 \\
$\mathbf{4}$ & $\mathbf{1 1 . 8 9 5}$ & $\mathbf{1 0 2 1}$ & $\mathbf{1 0 2 6}$ & $\mathbf{1 , 8}$-cineol & $\mathbf{6 . 2 3}$ & $\mathbf{5 . 1 3}$ \\
$\mathbf{5}$ & $\mathbf{1 4 . 2 1 4}$ & $\mathbf{1 0 9 1}$ & $\mathbf{1 0 9 5}$ & linalool & $\mathbf{7 9 . 5 5}$ & $\mathbf{7 9 . 5 9}$ \\
6 & 17.095 & 1181 & 1186 & $\alpha$-terpineol & 0.49 & 0.46 \\
7 & 18.587 & 1229 & 1235 & neral & 0.18 & 0.15 \\
$\mathbf{8}$ & $\mathbf{1 8 . 9 5 0}$ & $\mathbf{1 2 4 1}$ & $\mathbf{1 2 4 9}$ & geraniol & $\mathbf{9 . 7 2}$ & $\mathbf{9 . 2 2}$ \\
9 & 19.447 & 1258 & 1264 & geranial & 0.17 & 0.89 \\
10 & 19.982 & 1275 & 1287 & bornila acetat & 0.25 & 0.58 \\
11 & 22.700 & 1369 & 1359 & neril acetat & 0.02 & 0.16 \\
12 & 23.091 & 1382 & 1389 & $\beta$-elemene & 0.30 & 0.33 \\
13 & 24.000 & 1415 & 1417 & (E)-caryophyllene & 0.23 & 0.16 \\
14 & 24.260 & 1424 & 1432 & $\alpha$-(E)-bergamotene & 1.94 & 1.47 \\
15 & 24.413 & 1430 & 1437 & $\alpha$-guaien & 0.17 & 0.19 \\
16 & 25.660 & 1476 & 1484 & D germacrene & 0.49 & 0.35 \\
17 & 26.272 & 1498 & 1509 & $\alpha$-bulnesene & 0.15 & 0.14 \\
18 & 26.495 & 1507 & 1513 & $\gamma$-cadinene & 0.51 & 0.33 \\
19 & 29.729 & 1636 & 1638 & epi-a-cadinol & 1.48 & 1.12 \\
\hline
\end{tabular}

${ }^{1}$ CRI: Calculated retention index; ${ }^{2}$ LRI: Literature retention index; ${ }^{3}$ GC-FI: Flame ionization gas chromatography.

The $\mathrm{LD}_{50}$ values of the products and the parameters obtained by the toxicity tests are available in Table 2. The mathematical models with the best fit for the linalool, essential oil, and insecticides can be visualized in Figure 1. In according to the Figure 1, the mortality of larvae increases as the dose increases for all products, but total mortality of larvae was not reach at the same concentration for all products. 
Table 2. Summary of the parameters obtained by the acute toxicity test of linalool, Ocimum basilicum essential oil, deltamethrin, and Decis against larvae of Spodoptera frugiperda.

\begin{tabular}{|c|c|c|c|c|c|}
\hline \multirow{4}{*}{ Linalool } & Time & $\mathbf{L D}_{50}{ }^{\mathrm{a}}$ & CI $95 \%{ }^{b}$ & $\mathbf{D F}^{\mathfrak{c}}$ & $\chi^{2 \mathrm{~d}}$ \\
\hline & & $\mu \mathrm{L} \mu \mathrm{L}^{-1}$ & & & \\
\hline & $24 \mathrm{~h}$ & 0.190 & $0.149-0.232$ & 10 & 9.94 \\
\hline & $48 \mathrm{~h}$ & 0.177 & $0.132-0.215$ & 9 & 6.70 \\
\hline \multirow[t]{3}{*}{ O. basilicum essential oil } & & $\mu \mathrm{L} \mu \mathrm{L}^{-1}$ & & & \\
\hline & $24 \mathrm{~h}$ & 0.401 & $0.244-0.529$ & 8 & 34.42 \\
\hline & $48 \mathrm{~h}$ & 0.398 & $0.206-0.428$ & 8 & 42.81 \\
\hline \multirow[t]{3}{*}{ Deltamethrin* } & & $10^{-3} \mu \mathrm{g} \mu \mathrm{L}$ & & & \\
\hline & $24 \mathrm{~h}$ & 19.250 & $8.960-29.540$ & 22 & 30.44 \\
\hline & $48 \mathrm{~h}$ & 17.260 & $7.810-27.110$ & 21 & 23.13 \\
\hline \multirow[t]{3}{*}{ Decis } & & $\mu \mathrm{g} \mu \mathrm{L}^{-1}$ & & & \\
\hline & $24 \mathrm{~h}$ & 0.249 & $0.173-0.359$ & 7 & 23.657 \\
\hline & $48 \mathrm{~h}$ & 0.250 & $0.173-0.359$ & 7 & 23.657 \\
\hline
\end{tabular}

${ }^{a}$ LD: Lethal dose; ${ }^{b}$ CI: Confidence interval; ${ }^{c}$ DF: Degrees of freedom; ${ }^{d} \chi^{2}$ : Chi-square; *Data obtained from Silva et al. (2017);
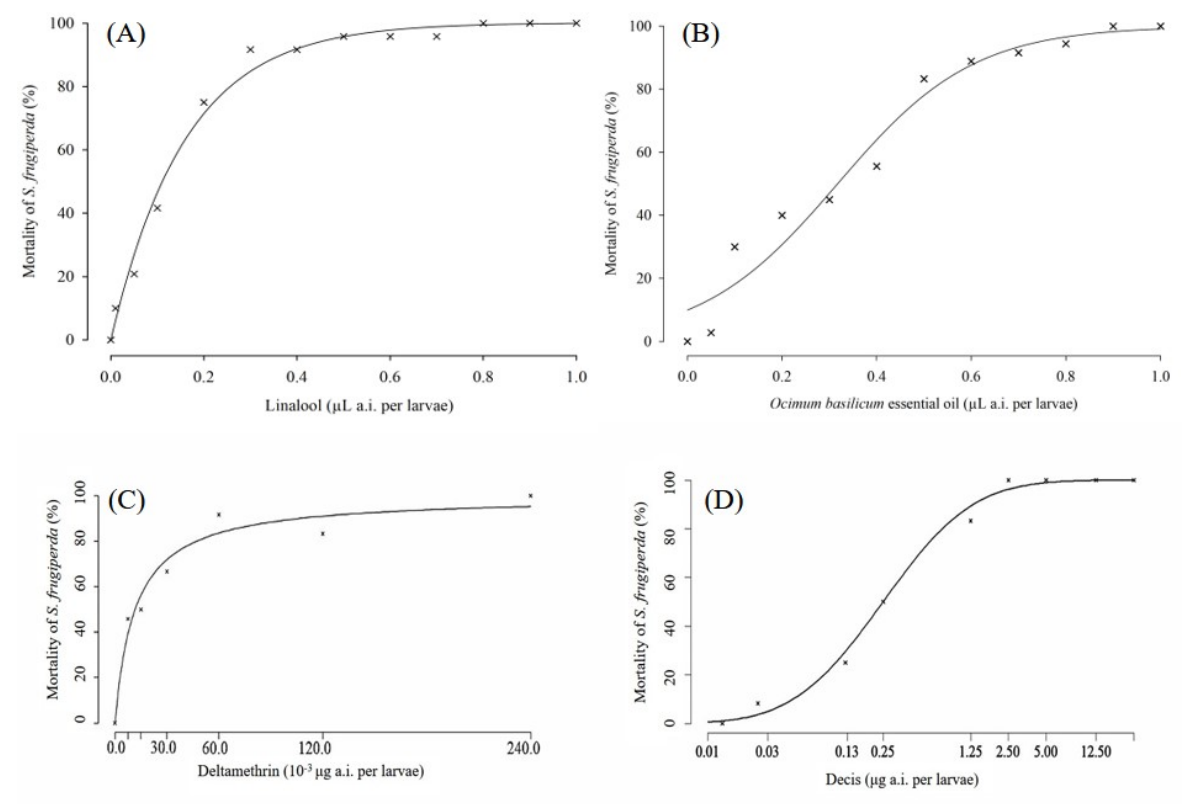

Figure 1. Mortality of $3^{\text {rd }}$ instar larvae of Spodoptera frugiperda after $48 \mathrm{~h}$ of acute toxicity with different doses of linalool (A), Ocimum basilicum essential oil (B), deltamethrin (C) and Decis (D).

After the application of linalool, it was observed extreme insect agitation, loss of motor coordination, loss of spatial orientation, extravasation of hemolymph, loss of feeding capacity, and death. It was also observed a high penetration capacity of the product with fast absorption by the cuticle of the insects. It was also observed that the higher the product dose, the more pronounced were the behavioral effects. Finally, the death of several individuals occurred a few moments after the application.

Regarding the essential oil, after its application, the observed behavioral effects were the same described previously, but in a more lenient way. After the pyrethroids application, the behavioral effects observed in insects were more subtle in relation to linalool, with little or no movement of the caterpillars, loss of motor coordination, and more prolonged death of the individuals, with maximum mortality occurring up to 48 hours after the application.

\section{Lethal effect of product mixtures against $S$. frugiperda larvae}

All binary mixtures caused mortality higher than the products applied alone (deltamethrin and 
linalool) used at $100 \% \mathrm{LD}_{50}$, except to $75 \% \mathrm{LD}_{50}$ of deltamethrin added to $25 \% \mathrm{LD}_{50}$ linalool, whose mortality did not differ the products alone, in 24 hours (Table 3). At highest dose of linalool, over $90 \%$ larval mortality occurs when linalool was combined with $25 \% \mathrm{LD}_{50}$ deltamethrin, in 24 and 48 hours after application (Table 3 ), and over $80 \%$ of mortality when linalool was combined with $25 \%$ $\mathrm{LD}_{50}$ Decis, in $48 \mathrm{~h}$ after application (Table 4).

Table 3. Mortality of larvae of Spodoptera frugiperda after topical application of linalool ( $\mu \mathrm{L}$ of active ingredient per $\mu \mathrm{L})$ combined with deltamethrin $\left(10^{-3} \mu \mathrm{g}\right.$ of active ingredient per $\left.\mu \mathrm{L}\right)$.

\begin{tabular}{|c|c|c|c|c|c|}
\hline \multicolumn{2}{|c|}{ Deltamethrin } & \multicolumn{2}{|c|}{ Linalool } & \multicolumn{2}{|c|}{ Mortality (\%) } \\
\hline Dose & $10^{-3} \mu \mathrm{g}$ a.i. $\mu \mathrm{L}^{-1}$ & Dose & $\mu \mathrm{L}$ a.i. $\mu \mathrm{L}^{-1}$ & $24 \mathrm{~h}$ & $48 \mathrm{~h}$ \\
\hline${ }^{\mathrm{a}} \mathrm{LD}_{50}$ & 19.25 & $\mathrm{LD}_{50}$ & 0.177 & $87.25 \mathrm{a}^{*}$ & $100.00 \mathrm{a}$ \\
\hline $50 \% \mathrm{LD}_{50}$ & 9.62 & $\mathrm{LD}_{50}$ & 0.177 & $95.75 \mathrm{a}$ & $95.75 \mathrm{a}$ \\
\hline $\mathrm{LD}_{50}$ & 19.25 & $50 \% \mathrm{LD}_{50}$ & 0.088 & $91.50 \mathrm{a}$ & $95.75 \mathrm{a}$ \\
\hline $25 \% \mathrm{LD}_{50}$ & 4.81 & $75 \% \mathrm{LD}_{50}$ & 0.132 & $91.50 \mathrm{a}$ & $91.50 \mathrm{a}$ \\
\hline $50 \% \mathrm{LD}_{50}$ & 9.62 & $50 \% \mathrm{LD}_{50}$ & 0.088 & $78.75 b$ & $78.75 \mathrm{a}$ \\
\hline $75 \% \mathrm{LD}_{50}$ & 14.43 & $25 \% \mathrm{LD}_{50}$ & 0.044 & $58.00 \mathrm{c}$ & $70.00 \mathrm{~b}$ \\
\hline $\mathrm{LD}_{50}$ & 19.25 & 0 & 0 & $53.75 \mathrm{c}$ & $58.00 \mathrm{c}$ \\
\hline 0 & 0 & $\mathrm{LD}_{50}$ & 0.177 & $45.75 c$ & $58.00 \mathrm{c}$ \\
\hline \multicolumn{4}{|c|}{ Control (Acetone) } & 0 & 0 \\
\hline \multicolumn{4}{|c|}{$\mathrm{F}^{\mathrm{b}}$} & 15.30 & 23.23 \\
\hline \multicolumn{4}{|c|}{$\mathrm{CV}(\%)^{\mathrm{c}}$} & 23.10 & 17.31 \\
\hline
\end{tabular}

* Means followed by lowercase letters in the column differ by the Scott-Knott test at $5 \%$ of probability; ${ }^{a}{ }^{2} D_{50}$ : Lethal dose for $50 \%$ mortality at $95 \%$ confidence interval; ${ }^{b} \mathrm{~F}$ : F value calculated; ${ }^{\mathrm{c}} \mathrm{CV}$ : Coefficient of variation.

Table 4. Mortality of larvae of Spodoptera frugiperda after topical application of linalool ( $\mu \mathrm{L}$ of active ingredient per $\mu \mathrm{L})$ combined with Decis ${ }^{\circledR}(25 \mathrm{CE})(\mu \mathrm{g}$ of active ingredient per $\mu \mathrm{L}$ ).

\begin{tabular}{|c|c|c|c|c|c|}
\hline \multicolumn{2}{|c|}{ Decis } & \multicolumn{2}{|c|}{ Linalool } & \multicolumn{2}{|c|}{ Mortality (\%) } \\
\hline Dose & $\mu$ g a.i. $\mu \mathrm{L}^{-1}$ & Dose & $\mu \mathrm{L}$ a.i. $\mu \mathrm{L}^{-1}$ & $24 \mathrm{~h}$ & $48 \mathrm{~h}$ \\
\hline${ }^{a} \mathrm{LD}_{50}$ & 0.25 & $\mathrm{LD}_{50}$ & 0.177 & $100.00 \mathrm{a} *$ & $100.00 \mathrm{a}$ \\
\hline $50 \% \mathrm{LD}_{50}$ & 0.125 & $\mathrm{LD}_{50}$ & 0.177 & $83.33 \mathrm{a}$ & $83.33 \mathrm{a}$ \\
\hline $25 \% \mathrm{LD}_{50}$ & 0.062 & $75 \% \mathrm{LD}_{50}$ & 0.132 & $77.00 \mathrm{a}$ & $83.00 \mathrm{a}$ \\
\hline $50 \% \mathrm{LD}_{50}$ & 0.125 & $50 \% \mathrm{LD}_{50}$ & 0.088 & $72.00 \mathrm{a}$ & $72.00 \mathrm{a}$ \\
\hline $75 \% \mathrm{LD}_{50}$ & 0.187 & $25 \% \mathrm{LD}_{50}$ & 0.044 & $72.00 \mathrm{a}$ & $77.00 \mathrm{a}$ \\
\hline 0 & 0 & $\mathrm{LD}_{50}$ & 0.177 & $44.33 b$ & $49.66 b$ \\
\hline $\mathrm{LD}_{50}$ & 0.25 & 0 & 0 & $44.33 b$ & $44.33 b$ \\
\hline \multicolumn{4}{|c|}{ Control (Acetone) } & 0 & 0 \\
\hline \multicolumn{4}{|c|}{$F^{b}$} & 29.32 & 25.39 \\
\hline \multicolumn{4}{|c|}{$\mathrm{CV}(\%)^{\mathrm{c}}$} & 12.76 & 16.24 \\
\hline
\end{tabular}

* Means followed by lowercase letters in the column differ by the Scott-Knott test at $5 \%$ of probability; ${ }^{\text {a }} \mathrm{LD}_{50}$ : Lethal dose for $50 \%$ mortality at $95 \%$ confidence interval; ${ }^{b} \mathrm{~F}$ : $\mathrm{F}$ calculated value; ${ }^{\mathrm{c}} \mathrm{CV}$ : Coefficient of variation.

\section{DISCUSSION}

\section{Products toxicity}

The obtained results confirmed the insecticidal potential of linalool. Its $\mathrm{LD}_{50}$ was lower than essential oil $\mathrm{LD}_{50}$, being half of it. The lower toxicity of the essential oil was already expected because, in its chemical composition, linalool was present in a lower concentration (79.29\%).

Previous studies concluded that the bioactive compounds present in the essential oils of aromatic species can interact synergistically and provide higher toxicity to the pests, concerning the exclusive application of some compounds
(AKHTAR et al., 2012; AFSHAR et al., 2017). Differently in the present work, the exclusive application of linalool caused higher toxicity than the essential oil of $O$. basilicum application. Koul et al. (2013) also showed higher toxicity of linalool to caterpillars, obtaining $\mathrm{LD}_{50}$ of $85.5 \mu \mathrm{g}$ per larva of Spodoptera litura (Fab.) (Lepidoptera: Noctuidae).

The observed effects after the linalool application are possibly related to the neurotoxicity of this compound since the insects presented an aspect of confusion, followed by extreme agitation and death. Pavela (2014) also confirmed the neurotoxic effects of this terpenoid. Previous studies have shown that linalool forms a stable 
intermolecular complex with the enzyme AChE, effectively inhibiting its interaction with acetylcholine (PRAVEENA; SANJAYAN, 2011), confirming the insecticidal potential of this compound.

As for the pyrethroids, the obtained results were remarkably close to the values obtained by Silva et al. (2017) like high toxicity, followed by caterpillar mortality. This underscores the effectiveness of this chemical group and the continuity of its application in the productive systems since appropriate measures are adopted to reduce the resistance of pests to insecticides.

On the other hand, as observed, $\mathrm{LD}_{50}$ linalool and essential oil values were higher than the values obtained for the pyrethroids. This fact could lead to questioning the real effectiveness of the former in relation to the latter. This happens because the pyrethroids present a different route of action in relation to linalool, presenting more intracellular action, specifically in the channels of $\mathrm{Na}^{+}$ions, in the cells of the nervous system.

The terpenoids act in the cholinergic system, in the region of the synaptic clefts, in an intercellular form, inhibiting neurotransmitters and receptors. According to Lopez; Villalobos (2010), a higher concentration of linalool would be required for it to be considered a potent inhibitor of $\mathrm{AChE}$ enzyme in relation to other insecticides that act on the same route. Lima et al. (2009) also reported higher doses of the terpenoid to control $S$. frugiperda.

It is also believed that lepidopteran pests have characteristics that make their control somewhat difficult. These characteristics would be related to a greater aggressiveness of their young forms in the competition for food, with a higher capacity of exploration and search for other hosts (polyphagous). Besides that, a greater capacity of detoxification and metabolization of xenobiotics (insecticides), being this, which make them more resistant to insecticides with different mechanisms of action, in relation to other insects.

All these characteristics indicate the urgent need to adopt more integrated management practices in agricultural systems, such as the constant rotation of products with different mechanisms of action and the application in the young stages of the corn fall armyworm, in propitiating the reduction of their population density, and consequently, their possible damages to the culture.

Lethal effect of product mixtures against $S$. frugiperda larvae
The results of synergist effect of binary combinations of linalool and pyrethroids were similar to others toxicological studies. Fazolin et al. (2016) obtained significant control of $S$. frugiperda in the combination of pyrethroids and terpenoids. In this study, the alpha-cypermethrin, fenpropathrin, gamma-cyhalothrin, and beta-cypermethrin $\mathrm{LD}_{50}$ were reduced to $1 / 2$ and/or $1 / 4$ in the presence of terpenoids, causing significant acute toxicity to larvae.

Abbassy et al. (2009) tested the synergistic effect of $\gamma$-terpinene and terpinen-4-ol with profenofos insecticide against Spodoptera littoralis (Boisd.) (Lepidoptera, Noctuidae). The results indicated that the isolated compounds enhanced the effectiveness of the insecticides against the tested insect.

Kariuki et al. (2014) reported that the association between products contributes significantly to increase the effectiveness of insecticides, and this tool is aimed at improving the management of resistance to insecticides. Srivastava et al. (2011) also emphasized that such combinations may cause faster effects on target organisms than synthetic formulations applied alone, possibly due to the greater complexity to metabolize different compounds combined in insect organisms.

The results of synergist effect of binary combinations of linalool and pyrethroids were very promising as more sustainable option in the pest management resistance to insecticides. In addition, the synergistic effect may lead to the reduction of the application rates of these insecticides which would be less harmful to the environment. The synergistic effect of this essential oil with insecticides could help to decrease the negative effects of synthetic chemicals such as residues in products, development of insect resistance, food contamination, and environmental pollution (ABBASSY et al., 2009).

According to the results found in the present work, the lethal doses of essential oil and linalool were higher than the doses of the synthetics insecticides, that is, to cause the same mortality of Spodoptera frugiperda caterpillars, greater quantities of natural products were needed in relation to the synthetics insecticides. As the content of the essential oil of Ocimum basilicum is extremely low (2\%), obtaining large quantities of the oil becomes awfully expensive. Thus, at present, it is believed that the most viable option for the applicability of natural products in field pest management would be in combination with 
synthetic insecticides, requiring lesser amounts of natural products to make their use feasible.

\section{CONCLUSION}

Linalool is highly toxic against Spodoptera frugiperda larvae $\left(\mathrm{LD}_{50}\right.$ of $\left.0.177 \mu \mathrm{L}_{\mu} \mathrm{L}^{-1}\right)$ and cause neurotoxic effects, which culminate in its death.

All binary product mixtures produced synergistic lethal effects under laboratory conditions.
Further studies are required in order to evaluate the synergistic combinations against field populations of $S$. frugiperda.

\section{ACKNOWLEDGMENT}

We thank the Coordination of Improvement of Higher Education Personnel - CAPES in supporting this work financially and the Agrarians Sciences Institute - ICIAG of the Federal University of Uberlandia - UFU to provide conditions for the development of this study.

RESUMO: O objetivo deste trabalho foi determinar a toxicidade do linalol e avaliar os efeitos tóxicos e letais do linalol associado a piretroides em misturas binárias para lagarta do cartucho do milho (Spodoptera frugiperda). Os insetos utilizados no experimento foram obtidos de criação estoque iniciada a partir de larvas coletadas em plantas de milho convencional, cultivado em área experimental, no município de Uberlândia, Minas Gerais. Também foi obtido óleo essencial de uma variedade de Ocimum basilicum, com alto teor de linalol (80\%), encontrado naturalmente, como medida de comparação para ensaios com linalol (97.5\%). Os bioensaios do tipo dose-resposta com larvas de $3^{\circ}$ instar foram realizados para determinar a dose letal do linalol para $50 \%$ de mortalidade da população $\left(\mathrm{DL}_{50}\right)$. Também foram realizados testes de toxicidade com óleo essencial de Ocimum basilicum e com inseticidas piretroides: deltametrina e seu produto comercial (Decis 25 EC, Bayer ${ }^{\circledR}$ ). Em seguida, foram realizadas combinações entre diferentes doses desses produtos e aplicadas em larvas de $3^{\circ}$ instar de Spodoptera frugiperda (Smith). De acordo com os resultados, observou-se que o linalol apresentou alta toxicidade para S. frugiperda $\left(\mathrm{DL}_{50}=0,177 \mu \mathrm{L}\right.$ a. i. $\left.\mu \mathrm{L}^{-1}\right)$. Foram observados efeitos neurotóxicos após a aplicação do linalol, uma vez que os insetos apresentaram um aspecto de confusão, seguido de extrema agitação e, por fim, morte. Todas as combinações binárias causaram mortalidade maior que os produtos aplicados isoladamente (deltametrina e linalol) utilizando-se $100 \%$ da $\mathrm{DL}_{50}$, exceto para $75 \% \mathrm{DL}_{50}$ de deltametrina somada a $25 \% \mathrm{DL}_{50}$ de linalol, cuja mortalidade não diferiu dos produtos isolados, em 24 horas após a aplicação. Foi obtida mais de $90 \%$ de mortalidade de larvas quando se combinou linalol com $25 \%$ da $\mathrm{DL}_{50}$ de deltametrina, em 24 e 48 horas após a aplicação, e mais de $80 \%$ de mortalidade quando se combinou linalol com $25 \%$ da $\mathrm{DL}_{50}$ do produto comercial, somente 48 horas após a aplicação. Concluímos que o linalol é um potencial inseticida e pode ser associado a piretroides no controle de $S$. frugiperda. Mais estudos são necessários em vista de avaliar as combinações sinérgicas contra populações de campo de $S$. frugiperda.

Terpenoides.

PALAVRAS-CHAVES: Atividade inseticida. Deltametrina. Sinergismo. Spodoptera frugiperda.

\section{REFERENCES}

ABBASSY, M. A.; ABDELGALEI, S.A.M.; RABIE, R.Y. Insecticidal and synergistic effects of Majorana hortensis essential oil and some of its major constituents. Entomologia Experimentalis et Applicata, Groningen, v. 131, n. 3, p. 225-232, 2009. https://doi.org/10.1111/j.1570-7458.2009.00854.x

ADAMS, R. P. Identification of Essential Oil Components by Gas Chromatography/Mass Spectroscopy. 3rd ed. Carol Stream: Allured Publishing Corporation, 2007, 804p.

AFSHAR, F. H.; MAGGI, F.; IANNARELLI, R.; CIANFLAGIONE, K.; ISMAN, M. B. Comparative toxicity of Helosciadium nodiflorum essential oils and combinations of their main constituents against the cabbage looper, Trichoplusiani (Lepidoptera). Industrial Crops and Products, Amsterdam, v. 98, n. 1, p. 46-52, 2017. https://doi.org./10.1016/j.indcrop.2017.01.004. 
AKHTAR, Y. L.; PAGES, E.; STEVENS, A.; BRADBURY, R.; CAMARA, C. A. G.; ISMAN, M. B. Effect of chemical complexity of essential oils on feeding deterrence in larvae of the cabbage looper. Physiological Entomology, Oxford, v. 37, n. 1, p. 81-91, 2012. https://doi.org/10.1111/j.1365-3032.2011.00824.x.

BAGAVAN, A.; KAMARAI, C.; RAHUMAN, A. A.; ElANGO, G.; ZAHIR, A. A.; PANDIYAN, G.

Evaluation of larvicidal and nymphicidal potential of plant extracts against Anopheles subpictus Grassi, Culex tritaeniorhynchus Giles and Aphis gossypii Glover. Parasitology Research, New York, v. 104, n. 5, p. 11091117, 2009. https://doi.org/10.1007/s00436-008-1295-7.

FARAONE, N.; HILLIER, N. K.; CUTLER, G. C. Plant essential oils synergize and antagonize toxicity of different conventional insecticides against Myzus persicae (Hemiptera: Aphididae). Plos One, San Francisco, v. 10, n. 5, p. 01-12, 2015. https://10.1371/journal.pone.0127774.

FAZOLIN, M.; ESTRELA, J. L. V.; MEDEIROS, A. F. M.; SILVA, I. A.; GOMES, L. P.; SILVA, M. S. F. Synergistic potential of dillapiole-rich essential oil with synthetic pyrethroid insecticides against fall armyworm. Ciência Rural, Santa Maria, v. 46, n. 3, p. 382-388, 2016. https://doi.org/10.1590/0103$\underline{8478 \mathrm{cr} 20141500 .}$.

ISMAN, M. B.; MIRESMAILLI, S.; MACHIAL, C. Commercial opportunities for pesticides based on plant essential oils in agriculture, industry and consumer products. Phytochemistry Reviews, Dordrecht, v. 10, n. 2, p. 197-204, 2011. https://doi.org./10.1007/s11101-010-9170-4

KARIUKI, D. K.; NJIRU, S. N.; MIARON, J. O.; MUGWERU, N. K. J. Synergistic bio-pesticide combination of pyrethrins and rotenoids for the control of the cockroach Americana periplaneta. Best: International Journal of Humanities, Greifswald, v. 2, n. 3, p. 43-48, 2014. https://profiles.uonbi.ac.ke/kkariuki/files/-1395726401-6. humanities-synergistic bio-pesticide-david_k. kariuki.pdf

KOUL, O.; SINGH, R.; KAUR, B.; KANDA, D. Comparative study on the behavioral response and acute toxicity of some essential oil compounds and their binary mixtures to larvae of Helicoverpa armigera, Spodoptera litura and Chilo partellus. Industrial Crops and Products, Amsterdam, v. 49, n. 1, p. 428-436, 2013. https://10.1016/j.indcrop.2013.05.032.

LANGAT, M. K.; CHEPLOGOI, P. K.; AROP, D. L.; SUM, K. S.; MOSES, R. K.; MICHURA, A. C. G. Flindersiamine, a Fluroquinoline alkaloid from Vepris uguenensis (Rutaceae) as a synergist to pyrethrins for the control of the housefly, Musca domestica L. (Diptera: Muscidae). Journal of Kenya Chemical Society, Nairobi, v. 6, n.1, p. 9-15, 2011.

LIMA, R. K.; CARDOSO, M. C.; MORAES, J. C.; MELO, B. A.; RODRIGUES, V. G.; GUIMARAES, P. L. Atividade inseticida do óleo essencial de pimenta longa (Piper hispidinervum C. DC.) sobre lagarta-docartucho do milho Spodoptera frugiperda (J. E. Smith, 1797) (Lepidoptera: Noctuidae). Acta Amazônica, Manaus, v. 39, n. 2, p. 377-382. 2009. https://doi.org/10.1590/S0044-59672009000200016.

LOPEZ, M. D.; VILLALOBOS, M. J. P. Mode of inhibition of acetylcholinesterase by monoterpenoids and implications for pest control. Industrial Crops and Products, Amsterdam, v. 31, n. 2, p. 284-288, 2010. https://10.1016/j.indcrop.2009.11.005.

MCLAFFERTY, F.W.; STAUFFER, D.B. The Willey /NBS Registry of Mass Spectral Data. 2nd ed. New York: John Willey, 1989, 1064p.

MALONE, L. A.; GATEHOUSE, A. M. R.; BARRATT, B. I. P. Beyond Bt: Alternative Strategies for Insect-Resistant Genetically Modified Crops. In: ROMEIS, J.; SHELTON, A. M.; KENNEDY, G. G. (Eds.). Integration of Insect-Resistant Genetically Modified Crops within IPM Programs. Progress in Biological Control. Dordrecht: Springer, 2008. https://doi.org/10.1007/978-1-4020-8373-0_13 
MURÚA, M. G.; NAGOSHI, R. N.; SANTOS, D. A.; HAY-ROE, M. M.; MEAGHER, R. L.; VILARDI, J. C. Demonstration using field collections that Argentina fall armyworm populations exhibit strain-specific host plant preferences. Journal of Economic Entomology, Oxford, v. 108, n. 5, p. 2305-2315, 2015. https://10.1093/jee/tov203

OECD/OCDE. Guidelines for the Testing of Chemicals. Honeybees, Acute Contact Toxicity Test. Leaflet $\mathrm{N}^{\circ}$ 214. Available from: <https://doi.org/10.1787/20745761> Accessed in January 232020.

OMOTO, C.; BERNARDI, O.; SALMERON, E.; SORGATTO, R. J.; DOURADO, P. M.; CRIVELLARI, A.; CARVALHO, R. A.; WILSE, A.; MARTINELLI, S.; HEAD, G. P. Field-evolved resistance to Cry1 Ab maize by Spodoptera frugiperda in Brazil. Pest Management Science, Oxford, v. 72, n. 9, p. 1727-1736, 2015. https://doi.org/10.1002/ps.4201.

PARRA, J. R. P.; CARVALHO, S.M. Biologia e nutrição quantitativa de Spodoptera frugiperda (J.E. Smith, 1797) em meios artificiais compostos de diferentes variedades de feijão. Anais da Sociedade Entomológica do Brasil, Londrina, v. 13, n. 2, p. 306-319, 1984.

PAVELA, R. Acute, synergistic, and antagonistic effects of some aromatic compounds on the Spodoptera littoralis Boisd. (Lep., Noctuidae) larvae. Industrial Crops and Products, Amsterdam, v. 60, n. 1, p. 247-258, 2014. https://10.1016/j.indcrop.2014.06.030.

PRAVEENA, A.; SANJAYAN, K. P. Inhibition of acetylcholinesterase in three insects of economic importance by linalool, a monoterpene prhytochemical. In: AMBROSE, D. P. (Ed.). Insect Pest Management, A Current Scenario. Palayamkottai, India: Entomology Research Unit, St. Xavier's College, 2011.

RADHIKA, S. A.; SAHAYARAJ, K. Synergistic effects of monocrotophos with botanical oils and commercial neem formulation on Spodoptera litura (Fab.) (Lepidoptera: Noctuidae). Journal of biopesticides, Tamilnadu, v. 7, p.152-159, 2014. https://www.researchgate.net/publication/265163087.

SANTOS-AMAYA, O. F.; TAVARES, C. S.; RODRIGUES, J. V. C.; SOUZA, T. C.; RODRIGUES-SILVA, N.; GUEDES, R. N. C.; ALVES, A. P.; PEREIRA, E. J. G. Magnitude and allele frequency of Cry1F resistance in field populations of the fall armyworm (Lepidoptera: Noctuidae) in Brazil. Journal of Economic Entomology, Annapolis, v. 110, n. 4, p.1770-1778, 2017. https://10.1093/jee/tox146.

SILVA, S. M.; CUNHA, J. P. A. R.; CARVALHO, S. M.; ZANDONADI, C. H. S.; MARTINS, R. C.; CHANG, R. Ocimum basilicum essential oil combined with deltamethrin to improve the management of Spodoptera frugiperda. Ciência e Agrotecnologia, Lavras, v. 41, n. 6, p. 665-675, 2017. https://doi.org/10.1590/1413-70542017416016317.

SILVA, K. F.; BALDIN, E. L. L.; PANNUTI, L. E. R. Use of botanical insecticides as an alternative for the management of the Mexican bean weevil. Revista Caatinga, Mossoró, v. 29, n. 2, p. 348-357, 2016. https://doi.org/10.1590/1983-21252016v29n211rc.

SPSS Inc, SPSS statistics for Windows, version 20.0. SPSS Inc., Chicago, 2011.

SRIVASTAVA, C. N.; MOHAN, L.; SHARMA, P.; MAURYA, P. A review on prospective of synergistic approach in insect pest management. Journal of Entomological Research, New Delhi, v. 35, n. 3, p. 255-266, 2011. https://www.researchgate.net/publication/285702156.

WANG, H.; LIAO, H.; OCHANI, M.; JUSTINIANI, M.; LIN, X.; YANG, L.; AL-ABED, Y.; WANG, H.; METZ, C.; MILLER, E. J.; TRACEY, K. J.; ULLOA, L. Cholinergic agonists inhibit HMGB1 release and improve survival in experimental sepsis. Nature Medicine, New York v. 10, n. 11, p.1216-1221, 2004. https://doi.org/10.1038/nm1124. 